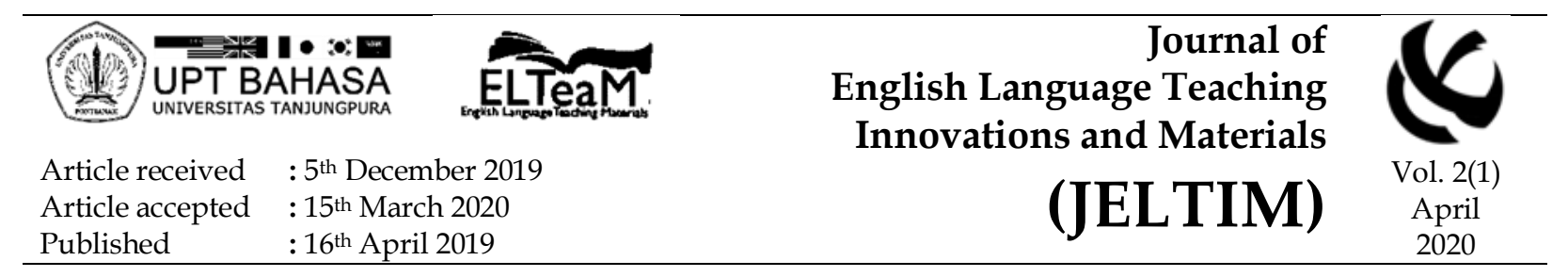

\title{
Using modified guided writing and role-play to motivate students to practice speaking
}

Susan Dewi 1, Yohanes Gatot Sutapa Yuliana 2, Melti Oktavianda ${ }^{3}$

${ }^{1}$ Master's Study Program of English Education, Faculty of Teacher Training and Education, Universitas Tanjungpura, Pontianak, Indonesia

Susandewi.smk5@gmail.com

2 Master's Study Program of English Education, Faculty of Teacher Training and Education, Universitas Tanjungpura, Pontianak, Indonesia

Gatot-fkip@yahoo.co.id

${ }^{3}$ Language Center, Universitas Tanjungpura, Pontianak, Indonesia

Melti.oktavianda@gmail.com

\section{DOI: http://dx.doi.org/10.26418/jeltim.v2i1.37833}

\begin{abstract}
The ability to speak in English is one of the requisite skills for vocational high school students majoring in hospitality training. However, most tenth-grade students manifested insufficient skills in speaking English, which resulted in low confidence in speaking. To cope with the challenge, the researchers implemented modified role-play and guided writing to stimulate students in speaking English in classroom action research. The procedure of the research consisted of planning, acting, observing and reflecting. The researchers employed observation, questionnaire, documentation and field notes in collecting the data. The research findings presented that the students' motivation to practice their speaking had increased significantly. Thus, the researchers conclude that roleplay and guided writing can be used as a communicative activity where students can simultaneously practise and improve their proficiency in communicating. The researchers also propose suggestion to fellow English teachers to effectively manage the time as well as engaging media to create an enjoyable atmosphere in the teaching-learning process through role-play and guided writing.
\end{abstract}

Keywords: guided writing; role-play; motivation; speaking

How to cite this paper: Dewi, S., Oktavianda, M., Yuliana, Y. G. S. (2019). Using modified guided writing and role-play to motivate students to practice speaking. Journal of English Language Teaching Innovations and Materials (JELTIM), 2(1), 3648. DOI: $\underline{\text { tttp://dx.doi.org/10.26418/jeltim.v2i1.37833 }}$

Journal of English Language Teaching Innovations and Materials (JELTIM), 2(1), 36-48

Copyright ( 2020 by JELTIM, e-ISSN 2657-1617 
Speaking is one of the fundamental language skills in addition to listening, reading, and writing that must be mastered by vocational students majoring in Hospitality Training Department. The competency in speaking is an essential part of the language and communication skills that the students will apply primarily in the profession they will later do. For those who will pursue jobs in Hospitality Training, they will always encounter foreigners who cannot speak Bahasa (Indonesian). This situation unquestionably requires them to master English, both oral and written. According to Thornbury (2007), spoken interaction involves producing and negotiating the language. Many spoken interactions consist of commenting on immediate actions or events (CelceMurcia, 2001; Richard, \& Renandya, 2002)

Based on Indonesian Curriculum 2006 that is well known as Kurikulum Tingkat Satuan Pendidikan (KTSP) or Education Unit Level Curriculum, the teacher's aim in teaching speaking at present is considered to be more focused on Communicative Language Teaching (CLT). CLT helps students into real-life communication where the teacher actively encourages students to apply speaking exercises authentically.

Freeman (2000) states that independence in communication is essential, given that CLT aims to apply the theoretical perspective of the communicative approach. Therefore, it makes communicative competence as the goal of language teaching. Teaching communicative language is a language teaching approach that emphasizes language learning first and foremost to communicate with others (Nunan, 2015, p. 10). Folse (2006) also states that for most people, the ability to speak is synonymous with knowing that language since speech is the most basic means of human communication. Diversity in interaction involves not only verbal communication but also paralinguistic elements of speech (Fulcher, 2003).

Student motivation is needed for the teaching and learning process because motivation is something that will guide students' behaviour towards specific goals. According to Lagabaster (2014), motivation can be defined as one of the principal keys for students in learning a foreign language or second language. In line with Lasagabaster, Butler (p.161) also states that there are seven characteristics of motivated students. As we know, there are two types of motivation, namely intrinsic and extrinsic motivation. Intrinsic motivation is an urge to do something because of the desire to know and feel it as a condition that must be fulfilled immediately. On the other hand, extrinsic motivation is the drive to do something outside of the action.

However, based on the preliminary observations as an educator who teaches at State Vocational School 5 Pontianak, it was revealed that most students had low achievements in English subjects, especially in achieving the speaking

Journal of English Language Teaching Innovations and Materials (JELTIM), 2(1), 36-48

Copyright ( 2020 by JELTIM, e-ISSN 2657-1617 
scores that students had done in their classrooms. The researchers also identified that pupils turned out to have less motivation in practising speaking. Furthermore, evidence revealed that out of 40 students, there are only ten or about $25 \%$ of students who can practice speaking well. For other students, they have not met the minimum requirements set. In addition, students have low motivation in practising speaking in class. Other specific problems identified were lack of fluency in speech, poor choice of diction, lack of vocabulary related to hotels or tourism, and lack of motivation to participate in the teaching and learning process.

Based on the problems that have been identified, researchers try to find suitable methods to improve students' speaking skills without ignoring other language skills. The teaching model chosen by the author in order to help students to be able to communicate with friends or other people both in the classroom and outside the classroom is role-playing.

The author chose this model to be implemented into research because this model encourages students to be able to position themselves as others in practising communication so that they become more creative, as well as providing opportunities for students to speak in different social contexts and roles. There are many functions of role play, but the two main functions of it are: "education for citizen" and "group counselling" which the teacher has done in the class (Wahab, 2009, p. 109).

The writer modified the process of teaching by giving some situations and asks them to make a dialogue after the teacher explained the material and gave an example of dialogue. A teacher asked the students to make a group of two (pair) and then made a dialogue depending on the situation given. Modification is a creative attempt by a teacher, then implementing a specific technique in his/her class. Previously, in a classroom action research, Ikhsanudin, Sudarsono, \& Salam (2019) also modified the mode of their class discussion. Through a combination of pair discussions, group discussion, cross-group discussion, and class discussion, they successfully improved the quality of students' engagement in classroom activities.

Richard (2006) affirms that communicative situations are models of events in which students will learn to handle various kinds of everyday situations in communication. These situations can occur on professional situations at office, academic situations that occur at school or university, situations when they need to make phone calls, informal situations when they talk casually with friends or even professional situations when they attend important meetings. Dorathy (2011) asserted that role-playing is a technique in which students carry out activities and communications that are appropriate to real environmental situations where they will be involved in cases or situations to show the same

Journal of English Language Teaching Innovations and Materials (JELTIM), 2(1), 36-48

Copyright ( 2020 by JELTIM, e-ISSN 2657-1617 
role information. Joyce \& Weil (2009, p. 29) also states that if one can emphasize role-playing, then he can interpret social events and interactions accurately.

In this model, the learners would practice in front of the classroom without bringing a note or book. Thus, the model which the author utilized in this research was the modification of role-playing and guided writing. In guided writing, the writer asks students to make a dialogue by changing the other expressions for the topic "Asking and Giving Directions". Usman (2016, p.30) remarks that by mastering the excellent technique for teaching writing, the teacher will be able to guide their students thoroughly.

One such technique that the teacher can use is the Guided Writing Technique (GWT). Ningsih (2016, p.131) asserted that guided writing is an individual or group activity where learners use word maps to organize their ideas and write texts.

The summary of the students' motivation in applying the model was unquestionably essential. It was used to show the whole research findings toward the implementation process of the model in cycle one at the first meeting. It was focused on activity one as it matched the questions in column A with the appropriate answer in column B. The activity consisted of 3 numbers of primary activities. The researchers asked some students to choose the right answers.

\section{METHOD}

Classroom action research (CAR) is defined as research which is accomplished by the teacher in a classroom and is a chain of 'research-actionresearch action". This classroom action research was conducted with the tenthgrade students of Hospitality Training Department of SMK Negeri 5 Pontianak (a vocational high school run by the city government) in Academic Year 2016/ 2017, by involving an English teacher and the school principal.

During this period, CAR has been carried out by many researchers to take actions and positive effects that will bring the desired changes to the progress of the quality of schools and students. According to Mills (2003, p. 5) in his book entitled "Action Research, a Guide for Teacher Researchers", Action research is considered a systematic investigation carried out by teachers, researchers, principals, schools, counsellors or other stakeholders in teaching and learning environment. In line with this, Budiyono and Ngumarno (2019) affirm that Classroom Action Research is a method that is conducive in increasing the responsiveness of lecturers to the dynamics of learning in the classroom as well as improve their professionalism.

This study aims to gather information about the quality of their schools, teaching and learning in the classroom, problems encountered, and the quality

Journal of English Language Teaching Innovations and Materials (JELTIM), 2(1), 36-48

Copyright ( 2020 by JELTIM, e-ISSN 2657-1617 
of student learning. The procedures that the writer applied in modifying roleplay activities and guided writing were in several procedures. The first procedure was to explain the expressions about asking and giving directions in cycle one and invitation in cycle 2 . Then, the teacher provided some examples of dialogue by using both materials. The teacher would act as a model to practice dialogue in front of the classroom. After that, the teacher asked the students to make a group of two or pair and to choose one situation given to make a dialogue by changing some expressions in a dialogue with others. The last step was to ask students to practice dialogue in front of the classroom without bringing a note.

The author attempted to modify the role-play model of teaching and guided writing by requiring the students to make a group of two, explaining the materials of "Asking and Giving Direction" and also giving an example of dialogue. Students matched questions in column A with the appropriate answer in column B. They proceed to ask and answer by looking at the panel. The students then practised in front of the classroom in pair by using role-play model of teaching. Liu \& Ding (2009, p.140) also affirmed that role play is an effective technique to animate the teaching and learning atmosphere, the interests of learners and make the language acquisition impressive.

The steps that the authors did in modified guided-writing and role-play model of teaching aimed to provide an example of dialogue and then asked the students to change some words with other expressions that could be used in asking and giving directions. Moreover, the authors gave situations that the students chose to make dialogues in the invitation, after that they practised without bringing text.

In this study, Classroom Action Research is carried out in several cycles. When the results desired by researchers and a cycle have not yet been achieved, the cycle will be revised to see the mistakes made. Then, the class action will be repeated in the next cycle. Each cycle begins with lesson planning, implementing plans (acting), observing implementation, and reflecting or evaluating the process and results of the implementation.

The planning included Beginner Reflect, Teaching Model Arrangement, and Creating Observation Form. Nevertheless, in the Acting step, the teacher is expected to perform according to the lesson plan. The researchers tried to encourage students to talk in English. The teacher also attempted to use the roleplaying teaching model because it allowed students to talk with their classmates.

On the other hand, in observing the teaching-learning process, the researchers were helped by collaborator teachers in the same subject. The researcher asked two other English teachers to observe her in conducting classroom action research while she was teaching in the classroom. One of the collaborators observed the writer during the observation in cycle 1 . However, in

Journal of English Language Teaching Innovations and Materials (JELTIM), 2(1), 36-48

Copyright ( 2020 by JELTIM, e-ISSN 2657-1617 
cycle 2, the writer observed one of the collaborators who implemented the roleplay model of teaching. The researchers gave the observation checklist both for teacher and student.

Furthermore, the authors reflected the purpose of the observation by doing another chain of actions that were carried out for the next meeting in cycle 2. It means that it is crucial to know the extent to which the acting has been carried out, evaluate and conducted the next cycle. Reflection in CAR consists of analysis, synthesis, and achievement of research implementation. If there is a problem that occurs in the process of reflection, the writer will proceed to the second cycle.

The subject of the research was the tenth-grade students majoring in Hospitality Training Department of SMK Negeri 5 Pontianak in Academic Year 2016/2017. The total of the students were 40, which consists of 31 females and nine males. The researchers applied the qualitative method in collecting data that concentrated on students' motivation and response in the learning process, for example, students have motivation in learning, students can answer questions given by the teacher, students can ask and answer questions as well. The data had been collected through observations and questionnaires in order to study how students respond to teacher questions in learning activities.

In analyzing data, the author used data analysis from field notes and observation lists. Students achievement in each cycle then was restored through increasing the range of scores from the assessment results. The average score here was used to classify the qualifications of student actions in conducting teaching using the role-playing model. This statement is in line with Erasma et al. (2012) who verifies that the research findings in this classroom action research proved that the role-playing technique shows a positive relationship to improving students' speaking proficiency.

\section{FINDINGS}

In the first cycle, the researchers found that students were enthusiastic about the exercises. Before conducting the teaching model, the researchers gave them dialogue hand-outs that were completed by students at home the day before taking action. The students could memorize the dialogue before they practised, so most of the students could do well because most of them wanted to try to practice in pairs with the model of teaching in front of the classroom without feeling embarrassed or afraid to performed afraid of making mistakes in answering the questions. Some students in group discussion were less active, and they were not confident to talk to their friends (see Table 1).

From the research findings of cycle 1, it can be seen that students can achieve most activities at the first meeting. It also appears that student

Journal of English Language Teaching Innovations and Materials (JELTIM), 2(1), 36-48

Copyright ( 2020 by JELTIM, e-ISSN 2657-1617 
participation in attending the teaching and learning process is considered excellent. It means that student motivation increases when compared to before doing the model. There were 28 students from 40 students who are proven to be motivated in learning. In addition, indicators of students struggling to express ideas in pairs are considered good too. In this activity, almost all students were involved, but only a few students did not seem to want to practice or speak.

Consequently, researchers aspired to employ Classroom Action Research to solve this motivation problem. The researchers applied the role-playing model so students could have motivation in learning. This model is proper for asking students to be more active and creative because they can express their thoughts with their friends in speaking.

In the second cycle, the researchers conducted an Acting Step in the learning process with different material and distinct ways. In an effort to improve students to practice speaking, collaborators neither provided assistance to students the day before nor let them do it at home. Nevertheless, collaborators asked students to have a dialogue or change a few words in a dialogue by using other expressions for 30 minutes in class.

There were around 28 students from 40 students who were proven to be motivated in learning. In addition, the indicators of students struggling to express ideas in pairs were considered good too. In this activity, almost all students were involved. Only a few students did not want to practice speaking. In implementing the model, some students still felt shy and afraid to practice. Overall, based on the findings taken in student motivation in learning, it can be perceived that the number of students practising is 28 students or 14 couples.

Meanwhile, almost $68 \%$ of students showed motivation and were involved in the teaching-learning process (see Figure 1). The results of the percentage of student motivation in conducting activities at the first meeting of cycle 1 were better than before. In performing role plays, some students did not want to try to practice speaking because they felt anxious and ashamed to make mistakes. They were also afraid that their friends would laugh at them if they practised it wrong. On the other hand, they had errors in choosing answers and in saying a few words in English text activity.

On the first meeting of cycle 2, collaborator guided in pre-activity as a simulation of the model. At first, the collaborator placed the students to sit on their seats and asked them to choose their friends with the highest score and with the lowest one. The form was in pair. Some students were chosen in a group by the collaborator - the students who gained the highest score in speaking test with the students who got the lowest one.

Journal of English Language Teaching Innovations and Materials (JELTIM), 2(1), 36-48

Copyright ( 2020 by JELTIM, e-ISSN 2657-1617 
Task cycle on the second meeting was the main activity of the model. It aimed to make the students wanted to try to practice speaking. At first, the collaborator asked the students to make a group of two (pair). The group consisted of the students with the highest score and the lowest one. In this activity, the students sat on their pair seats as the collaborator asked them to make a short dialogue about invitation based on the situation given in 30 minutes. After that, they had to practice their dialogue in front of the classroom without bringing a note. During this time, the collaborator reminded them to look at the example of dialogue before. They had to make a short dialogue depend on the five situations given.

Based on the finding taken in the students' motivation in learning, the achieved total of the students in practising in assessment was 34 or 17 pairs, while almost $84 \%$ students who had the motivation and got involved in the teachinglearning process. As a result, the percentage of the students' motivation in doing the activities in the first meeting of cycle 2 was better than in cycle 1 .

In this activity, almost all students got involved and had motivation in practice speaking. However, some students got a worse score in speaking in the second cycle. It was because they had to practice in 30 minutes preparing after conducting the material.

Overall, the achieved total score for the students' motivation in practising speaking in the teaching-learning process in the second meeting was $88 \%$ or for about 34 students of 40 . It was better than the first meeting, which was only $84 \%$. It meant that the students' motivation could increase (see Figure 2).

The collaborators asked the students to make a short dialogue based on the situation given. Before that, the collaborators provided an example of dialogue, and then the students made it in 30 minutes. Most of the students wanted to try, but they read a note, and only some students could do best without bringing any written notes.

\section{Figures}

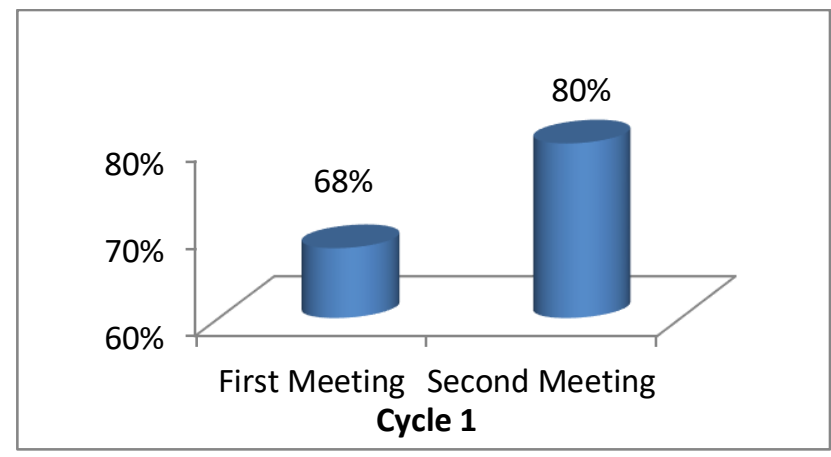

Figure 1. Students' Motivation in Cycle 1 (Source: Susan Dewi, 2020)

Journal of English Language Teaching Innovations and Materials (JELTIM), 2(1), 36-48

Copyright ( 2020 by JELTIM, e-ISSN 2657-1617 
Figure 1 above shows the learners' motivation in the first and second meeting of cycle 1 . Thus, researchers asked students regarding their problems and ascertained that almost all of them seemed not had the self-confidence to speak yet as they felt afraid and shy whenever they want to speak.

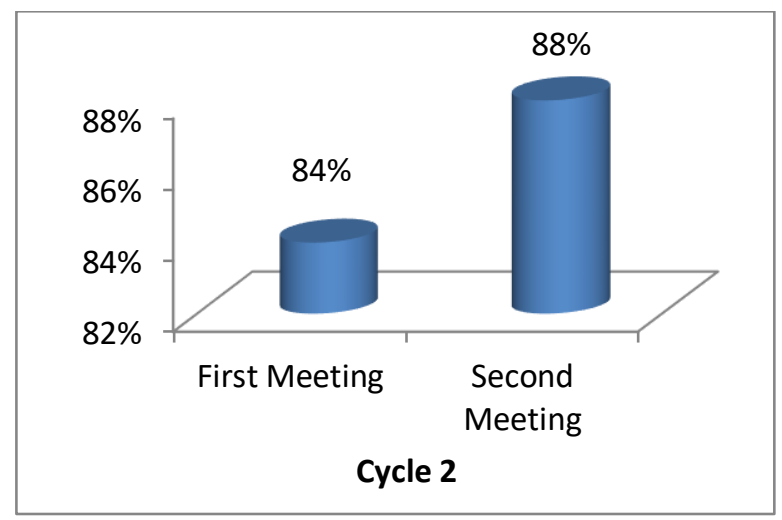

Figure 1. Students' Motivation in Cycle 2 (Source: Susan Dewi, 2020)

Figure 2 above depicts information about the achieved total score for the students' motivation in practising speaking in cycle 2 . As we can see, the second meeting was $88 \%$ or for about 34 students of 40 . It was better than the first meeting, which was only $84 \%$.

\section{Tables}

Table 1. The percentage of students' motivation before the model had been conducted

\begin{tabular}{clcc}
\hline No & \multicolumn{1}{c}{ Indicators } & Obtained & $\mathbf{0}$ \\
\hline \multirow{2}{*}{1.} & $\begin{array}{l}\text { Students were not focused on the lesson (played } \\
\text { cellular phone, pretended to read etc.) }\end{array}$ & 16 & $40 \%$ \\
\hline 2. & Students could answer the teacher's questions & 4 & $10 \%$ \\
\hline 3. & Students participated in the teaching-learning process & 12 & $30 \%$ \\
\hline 4. & Students raised their hands & 6 & $15 \%$ \\
\hline 5. & Students asked questions & 2 & $5 \%$ \\
\hline & Total & $\mathbf{4 0}$ & $\mathbf{1 0 0 \%}$ \\
\hline
\end{tabular}

(Source: Susan Dewi, 2019)

From the table above, it could be perceived that most of the learners had low motivation in learning. Thus, researchers asked students regarding their problems and ascertained that almost all of them seemed not had the selfconfidence to speak yet as they felt afraid and shy whenever they want to speak.

\section{DISCUSSION}

The findings of this study indicate that the application of role play in the teaching and learning process is successfully proven to motivate students to practice speaking in English. It can be regarded in the implementation of 
modified role-playing and guided-writing to assist and supervise students to understand dialogue in several real-life situations.

Students could communicate with their other friends in the process of speaking naturally through interaction with their friends in pairs. This model was also able to facilitate students to be involved and imitate other friends who have better competence in speaking English together. Therefore, this model allows them to have the courage to use "Expressions Asking and Giving Direction" and "Making and Responding to Invitations."

From the results of the study, it can be discerned that the understanding of the phrase "Asking and Giving Direction" is in accordance with the results of the research conducted by researchers in the first cycle, students can do their best. It can be observed from the presence of 34 students from 40 students at ten levels of the Hospitality Training Department who got good grades. That means that they can understand the expression above, and they did not feel bashful and hesitant to practice speaking in proper English with their teacher and their friends. In general, it can be assumed that students' abilities are quite good with role-playing models.

Meanwhile, in understanding the lesson in the second cycle, it was perceived that students' ability to practice speaking was lower than in the first cycle. This is because they had to practice in pairs after the teacher/researchers gave a lesson, so they were not brave and still feel embarrassed when they want to try talking. They did not know what they would do.

They could not do that before they memorize the dialogue, or they cannot practice directly. There were only ten pairs or twenty students from 40 who did it well even though they did not memorize the dialogue. The authors concerned that the second cycle was better than the first cycle. Although the total number of students who practised was lower than in the first cycle, the quality of students was notably better in the second cycle because they did not memorize the dialogue. However, they could practice after they make the dialogue in 30 minutes.

In the first cycle, the students practised guided-writing and role-play. 34 students of 40 in total successfully performed the dialogue with their pairs. Only six students failed to achieve the role-play. Based on the observation, they did not show shyness and fear. They also found this activity as an opportunity to practice speaking in different communication settings as well as develop their communication skills. It is a reflection of a notion by Louma $(2004, p .15)$ who states that role play stimulates different communication situations.

The second cycle was conducted in a slightly different method from the first cycle. While the first cycle let the students learn the dialogues through a

Journal of English Language Teaching Innovations and Materials (JELTIM), 2(1), 36-48

Copyright ( 2020 by JELTIM, e-ISSN 2657-1617 
handout, in the second cycle, the students were not given this handout. They were provided more opportunity to explore possible ways in the dialogue. It resulted in increasing motivation in practising speaking.

Moreover, most pairs showed enthusiasm and fluency in performing the role play. This study also confirms that students with high ability are willing to share their ideas with others who have less expertise. The second cycle has been a manifest of a theory that role-play helps individuals find their meaning in their social group (Joice, 2009, p. 290).

\section{CONCLUSION}

According to the results of this study, the authors concluded that modified role-play and guided-writing proved successful in encouraging the students to enhance their motivation to practice speaking. It can also be perceived from several indicators as the students attend classes, pay attention to lessons, participate in classes, frequently ask questions, and attempt to express their ideas.

The researchers concluded that the modified role-play model of teaching and guided writing is an effective teaching model which can be used to motivate students to practice speaking. It is because role-playing is a group activity focused on the needs of the group. Furthermore, role-play can motivate the students to be more active in the discussion of the teaching-learning process. It is due to the fact that role-playing provides an opportunity to practice speaking in different communication settings as well as develops their communication skills. This model facilitated the students to get involved and to imitate the other friends that have better competence in English speaking as it helps individuals find their purpose in the social group.

The researchers also want to propose some valuable suggestions to be considered for fellow English teachers, students, and other researchers. First of all, for fellow English teachers, it will be beneficial if the teacher can prepare more learning aid and stimulating media to be used along with Role-Play. The use of these learning aids will give significant improvement to the classroom atmosphere and students' motivation. Furthermore, researchers advise the students to spend some time to practice English, both in and out of the classroom. They can also use the opportunity to practice independently in diverse social contexts and role with their classmates.

Lastly, the researchers are fully aware that this study still needs further improvement and investigation regarding the topic. Hence, it is suggested for fellow researchers to conduct an advanced study concerning the technique and efforts to improve students' motivation to learn English.

Journal of English Language Teaching Innovations and Materials (JELTIM), 2(1), 36-48

Copyright ( 2020 by JELTIM, e-ISSN 2657-1617 


\section{REFERENCES}

Budiyono, S., \& Ngumarno, N. (2019). Improving student learning achievements through application of the student teams achievement divisions (STAD) method. Journal of Applied Studies In Language,3(2), 140-147. doi: 10.31940/jasl.v3i2.1370

Butler, S., \& McMunn, N. (2011). A teacher's guide to classroom assessment. New York: Wiley.

Celce-Murcia, M., Brinton, D., \& Goodwin, J. (2001). Teaching pronunciation. New York: Cambridge University Press.

Dorathy, A. A. (2011). Second language acquisition through task-based approach role play in English language teaching. Journal ESP World ISSN1682-3257; Issue 33, Volume 11, 2011).

Erasma, Y., Sutapa, G., Salam, U. (2012). Improving students speaking ability in class through the role-play technique. Retrieved 22 August 2019, from http://jurnal.untan.ac.id/index.php/jpdpb/article.

Folse, K. (2006). The art of teaching speaking. Ann Arbor: University of Michigan Press.

Fulcher, G. (2003). Testing second language speaking. Harlow: Longman/Pearson Education

Ikhsanudin, I., Sudarsono, S., \& Salam, U. (2020). Using Magic Trick ProblemBased Activities to Improve Students' Engagement in a Listening Class. Retrieved 3 August 2019, from http://jurnal.untan.ac.id/index.php/JELTIM/article/view/31620

Joyce, B. (2009). MODELS OF TEACHING. United States of America: Pearson Education Inc.

Larsen-Freeman, D. (2000). Techniques and principles in language teaching. Oxford: Oxford University Press

Lasagabaster, D. (2014). Motivation and foreign language learning from theory to practice. Amsterdam: John Benjamin Publishing Company.

Liu, F., \& Ding, Y. (2009). Role-play in English Language Teaching. Asian Social Science, 5(10). doi: 10.5539/ass.v5n10p140

Mills, G. E. (2003). Action Research: A Guide for The Teacher Researchers (Vol. Second Edition). Columbus Ohio: Merrill Prentice Hall

Journal of English Language Teaching Innovations and Materials (JELTIM), 2(1), 36-48

Copyright ( 2020 by JELTIM, e-ISSN 2657-1617 
Ningsih, S. (2016). Guided writing to improve the students' writing ability of junior high school student. EFL Journal Vol 1.No.2,2016.www,efljournal,org.

Nunan, D. (2015). Teaching English to Speakers of Other Language. New York: 711 Third Avenue.

Richards, J. (2005). Communicative language teaching today. Singapore: SEAMEO Regional Language Centre.

Richards, J., \& Renandya, W. (2002). Methodology in Language Teaching. West Nyack, USA: Cambridge University Press.

Thornbury, S. (2007). How to teach vocabulary. Malasia: Longman.

Usman, B. (2016). Using the guided writing to improve the students' writing of analytical exposition texts. English Education Journal(EEJ), 7(1) 29- 45,

Wahab, A. A. (2009). Metode dan model-model mengajar. Bandung: ALfabeta.

\section{Authors' Brief CV}

Susan Dewi is a student of Master's Study Program of English Language Education of Universitas Tanjungpura, and a senior English teacher in a Vocational High Schools in Pontianak. She is also a Vice-Principal of the school. Her research interest is on overcoming problems faced by vocational students in learning English.

Yohanes Gatot Sutapa Yuliana. He is the Associate Professor and is actively teaching at the English Study Program at Tanjungpura University. In addition to teaching, he is a social activist who involves in rural development of non-formal education. He actualizes organization skill in English Language Teaching Materials Association (ELTeaM) chairing Publication Division (2012-now).

Melti Oktavianda. She is a lecturer who is currently teaching English for Specific Purposes in several faculties at Universitas Tanjungpura (UNTAN). She is also a TOEFL and IELTS trainer at UNTAN's Language Center. Her research interests are in the fields of Psycholinguistics and Academic English, especially in writing and speaking skills. 